\title{
E-Learning and Students' Motivation: A Research Study on the Effect of E-Learning on Higher Education
}

\author{
http://dx.doi.org/10.3991/ijet.v9i4.3465 \\ M. Samir Abou El-Seoud ${ }^{1}$, Islam A.T.F. Taj-Eddin ${ }^{1}$, Naglaa Seddiek ${ }^{1}$, \\ Mahmoud M. El-Khouly ${ }^{2}$, Ann Nosseir ${ }^{1}$ \\ ${ }^{1}$ British University in Egypt-BUE, Cairo, Egypt, ${ }^{2}$ Helwan University, Cairo, Egypt
}

\begin{abstract}
Most universities in Egypt face many educational problems and obstacles that technology can help to overcome. An open source, such as Moodle e-learning platform, has been implemented at many Egyptian universities. Moodle could be used as an aid to deliver e-content and to provide various possibilities for implementing asynchronous elearning web-based modules. This paper shows that the use of interactive features of e-learning increases the motivation of the undergraduate students for the learning process.
\end{abstract}

Index Terms-e-learning, higher education, motivation, web-based education.

\section{INTRODUCTION}

\section{A. Overview}

Web-based learning is used nowadays as another option to face to face education. As a matter of fact, its use increases in a direct proportion with the increase of the number of students. This has made educators exert a lot of effort to help the learners to get interactive content that is full of multimedia as it has been proven that it has a significant effect on the process of learning. The impact of blogs and wikis has also been investigated on learners' collaboration and reflection and it was reported that they both have a positive effect.

E-learning has been introduced as a tool in the learning process in the majority of the international universities worldwide. The term "e-learning" is defined by [9] as "any learning that involves using internet or intranet." A year later [8] made the definition more generalized by indicating that it is "anything delivered, enabled, or mediated by electronic technology for explicit purpose of learning" [17][18]. According to [7] " $\mathrm{e}$ " in e-learning should not stand for electronic; it should be an abbreviation for "evolving, enhanced, everywhere, every time and everybody." In fact, the quotation of [7] shows most of the advantages of e-learning for learners and instructors.

Although the e-learning term and tools do exist for over a decade, the educational research field has not given enough attention to the study of student motivation under the effect of e-learning.

E-learning has grown in significance as an educational tool just like technology has developed and progressed over the years. Interestingly, there have been more efforts at advancing technology than on attempting to understand the needs and learning styles of individual learners and instructional design. The 21 st century has seen rapid progress with such things as the Internet and online learning.
The increased use of e-learning among educational institutions has led to a change in higher education. According to findings, there has been a rise of about 12-14 percent annually in enrolment for online learning over a five year period: 2004-2009 after secondary education [2]. One of the main reasons for this is it gives students' greater access to education in comparison to traditional methods of teaching as students can undertake their study from anywhere and at any time as well as being given the option to study part-time or full-time [3]. E-learning has transformed the educational sector by enabling students to share information and data in a relatively easy way.

\section{B. Motivation}

Recent studies indicate that university students who have been enrolled on e-learning courses outperform those being taught on traditional courses. An example of this can be found at Carnegie Mellon University (CMU) in America where student exam results have shown improvement as a result of e-learning techniques [6]. It is therefore imperative that an education system is created which is capable of rapid adaption to its technological, social, cultural and political environment [1].

Incorporating technology in the learning process does not necessarily guarantee motivated students. In fact, online instruction has resulted in the student teacher relationship becoming less personal. Teachers are required to turn the classroom into an online environment. The question is what exactly is required of teachers to motivate students in an online environment? [5]

It is essential for teachers to understand their students' motivations. Although students take online courses with the intention of successfully completing them, they tend to fail for a number of reasons. The success or failure of online instruction is perhaps related to student motivation. To stimulate students, teachers should [13]:

1. keep in mind that motivation must be natured in students.

2. explain to their students how the online environment may be used.

3. encourage interaction and collaboration among their students.

4. build study groups so that students will no longer be studying in isolation.

5. help students to make friends by meeting fellow students in the online environment.

6. interact with their students by monitoring the online presence of them and supplying them with continuous feedback. 
7. construct their learning materials and environment to target their students.

8. facilitate the students' interaction with the online material by explaining the goal behind designated tasks.

9. be aware of students' frightened, worries and nervousness because such anxiety may have a negative effect on their accessibility and motivation.

All of these approaches could be crucial tools to develop new strategic teaching plans that might assist lecturers to influence learners' level of motivation.

Wlodkowski [11] claims that "learners learn more using computer-based instruction in comparison to traditional classroom methods." One possible factor for this seems to be the increased level of learner participation through interactivity. This results in higher levels of cognitive engagement and perseverance to complete the task.

Furthermore, studies also show that the success of elearning methods in higher education can only be measured according to the effectiveness of delivery. Therefore, the adoption of e-learning initiatives falls considerably on the training of staff which is really a major challenge. It has been acknowledged that many faculty members are reluctant in accepting aspects of technology in the teaching process. Unfortunately, teachers that are not welltrained might face difficulties in application use [12]. Moreover, in order for success to occur lecturers in higher educational institutions must accept, implement and adopt technological advancements offered by e-learning. Such new educational approaches are imperative in order to maintain the quality of courses [4]. Having said that, training lecturers on how to use e-learning to enhance teaching practices should not focus primarily on how to use the hardware and software [11], but rather on how to be adaptable to both formal and less formal teaching methods and techniques [10].

The instructor prepares the course material via a number of educational strategies to suit the different learning styles of students. Lecturers can use a number of strategies to highlight the goals of an assessment [13]:

1. Explain to students why the task is important and interesting to them. It may be useful to link the task to practices that the students may use in their professional life.

2. Define the learning objective of the task. Such objectives will identify the performance standards that a student needs to meet to reach the desired goal.

3 . Give advice in relation to the time required to complete the activity.

4. Provide preliminary exercises that the student can practice, thereby building their confidence and boosting their motivation

All these elements should help students to understand online exercise goals which in turn might increase their motivation.

Assessments can be formative, i.e. taken throughout the duration of the course or summative, at the end of the course [3]. The most appropriate method of obtaining the student's awareness is through a summative assessment, which is carried out towards the end of the course. The student's performance, or achievement, may be apparent throughout the course in the form of "homework, tests, and class discussions," but in many classroom activities learning "is fugitive, recordable only at great cost and inconvenience" [15]. However, e-learning tools can make module assessment more simplified by changing a difficult task into a more achievable one, by enabling an interactive approach to course assessment.

The cost of delivering online learning has to be minimal. Figure 1, illustrates that the cost of Internet access in Egypt is competitive in comparison to other countries (According to the World Bank price basket methodology), the monthly cost of Internet service in Egypt was USD 4.50 in 2007 , which compares favorably to the cost of its North African neighbors Morocco, Algeria and Tunisia [20]. Report [20] is the last report issued by the Ministry of Communication and Information Technology, Egypt, in 2009.

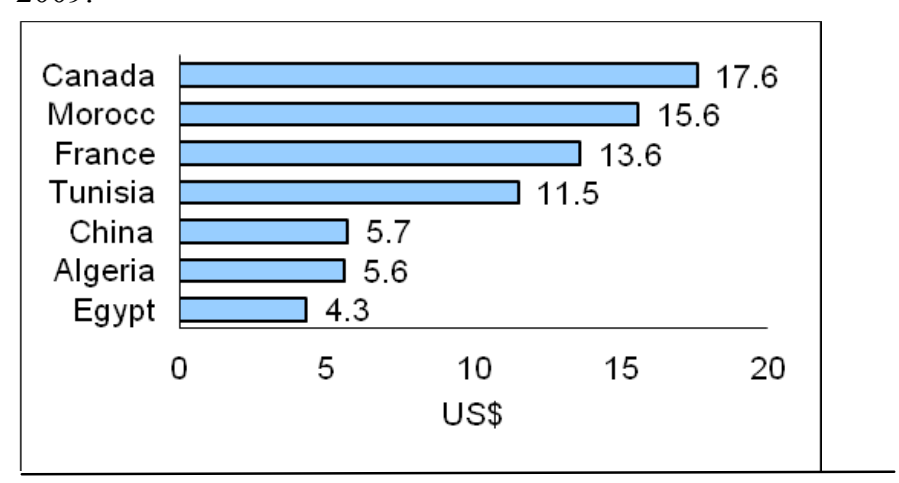

Figure 1. Internet access costs in different countries at 2007

Based on the above, the future lies in the integration of technological development within the different educational sectors as this will undoubtedly have a positive impact on course delivery and the learning process.

\section{Research hypothesis}

The main objective of this study was to measure to what extent using the interactive features of e-learning increases the motivation of undergraduate students for the learning process. The significance of this study is that it raises the awareness of academic staff to the importance of using the interactive features of e-learning as an important asset in teaching adult students.

In this study five research hypotheses were examined to determine which hypothesis should be accepted and which should be rejected.

H1: Students will show preference towards online activities as opposed to the traditional method of learning.

$\mathrm{H} 2$ : Students will show a difference in attitudes towards e-learning based on the students' degree year.

H3: Students will show a difference in attitudes towards e-learning based on the students' faculty.

H4: The exam score will influence the preference to online rather than the traditional approach

H5: The teacher has an impact on the students' willingness to use Web-based exercise

In this study, the p-value has been used to test the above hypotheses. P-value is a probability statement which answers the question: If the Null Hypothesis is true, then what is the probability of becoming aware of the test statistics at least as extreme as the one observed. A p-value of 0.05 or less rejects the null hypothesis 'at the $5 \%$ level' that is, the statistical hypothesis used suggests that only $5 \%$ of the time would the supposed statistical process to 
come to a finding to the utmost if the null hypothesis were true. $5 \%$ and $10 \%$ are common significance levels to which p-values are compared.

\section{RESEARCH METHOD AND PROCEDURES}

\section{A. Design and Approach}

To test the previous hypotheses, we ran three studies. The first study investigated hypotheses $\mathrm{H} 1, \mathrm{H} 2$, and $\mathrm{H} 3$ and the second study tested hypotheses H4 and H5. Each study collected quantitative feedback to evaluate the students' willingness to use e-learning. This paper is an extensive study based on the papers [14][16].

\section{B. Participants}

The participants of the experimental part of the research were students at the British University (BUE) [19] and Helwan University in Egypt [6]. Both universities have introduced e-learning as a learning tool to support traditional face-to-face lectures and they have relevant experience with online educational systems. They use Moodle version 2.0 and higher. E-learning has been used as an essential tool for the learning process across both universities. In this study e-learning had been used as a tool for the students to conduct interactive web-based exercises. Other Multimedia tools of the e-learning could be used in future studies. The survey was administered by instructors at the Faculty of Informatics and Computer Science (ICS) and the English Department at the (BUE)[19], as well as the Computer Science Department in the Faculty of Computers and Information at Helwan University[6]. This study was a part of a longitudinal effort to try to determine the use of technology in teaching within a higher educational context and to seek the various factors that affect students' motivation towards e-learning.

\section{STUDIES \& EVALUATIONS}

\section{A. Study 1}

This study investigated $\mathrm{H} 1, \mathrm{H} 2$, and $\mathrm{H} 3$ and was conducted with students in the English department at the (BUE)[19]. It is important to note that all students in the different depatments and faculties at the university are required to take English modules alongside their degree area modules.

The students were given two different exercises, namely Web-based Interactive and Paper-Based. The students were asked to answer both exercises at home in a two week period successively. They were informed that the exercises were not graded. The two exercises were balanced in terms of difficulty, number of questions, question types and the time given to answer each exercise.

Next, the students were given a questionnaire survey to complete. The questionnaire survey was adapted from Cheng (2006) and contained twelve questions with five different scales. The students were asked to choose one option of (Strongly Agree $=5$ points, Agree $=4$ points, Neither Agree or Disagree $=3$ points, Disagree $=2$ points, Strongly Disagree $=1$ points) for each question.

The questionnaire survey assessed the students' willingness to use e-learning and to measure attitudes towards e-learning for some specific modules. Table I presents the questionnaire survey used in the study.

Students were also asked to choose between two sets of paper-based and web-based exrcises, to solve in class, then to answer a questionnaire. Of the 159 students who participated in the study, 124 questionnaires were completed correctly and used in this study. The students who participated in the study were from the Faculties of ICS, Engineering, Political Science, Business, Pharmacy, and Dentistry. Students were in the prepapratory and first year.

For H1, the results revealed a significant difference between the students who had chosen web and paper-based exercises for answering questions 1, 6, 7, 8 and 9 $(\mathrm{P}<0.05)$, (see Figure 2).

TABLE I.

THE QUESTIONNAIRE USED IN THE STUDY FOR THE ENGLISH MODULE

\begin{tabular}{|l|l|}
\hline Q1 & I like using e-learning for English modules \\
\hline Q2 & $\begin{array}{l}\text { I think the teacher's application of e-learning in teaching } \\
\text { English modules helps me improve my skills in English }\end{array}$ \\
\hline Q3 & $\begin{array}{l}\text { I think the teacher's application of e-learning in teaching } \\
\text { English modules is not useful }\end{array}$ \\
\hline Q4 & $\begin{array}{l}\text { I think my grades will improve by using e-learning for Eng- } \\
\text { lish modules }\end{array}$ \\
\hline Q5 & $\begin{array}{l}\text { I find English modules easier when the teacher uses e- } \\
\text { learning in teaching }\end{array}$ \\
\hline Q6 & $\begin{array}{l}\text { I hope teachers of English continue to use e-learning in their } \\
\text { teaching }\end{array}$ \\
\hline Q7 & $\begin{array}{l}\text { Using e-learning for English modules is more interesting } \\
\text { than the traditional method }\end{array}$ \\
\hline Q8 & E-learning make me more interested in learning English \\
\hline Q9 & $\begin{array}{l}\text { By using e-learning for English modules, the opportunity of } \\
\text { interaction with the teacher is enhanced }\end{array}$ \\
\hline Q10 & $\begin{array}{l}\text { By using e-learning for English modules, the opportunity of } \\
\text { interaction with my classmates is enhanced }\end{array}$ \\
\hline Q11 & $\begin{array}{l}\text { Using e-learning for English modules encourages me to } \\
\text { continue learning on the Internet by myself }\end{array}$ \\
\hline Q12 & $\begin{array}{l}\text { I am unwilling to learn English modules through using e- } \\
\text { learning }\end{array}$ \\
\hline
\end{tabular}

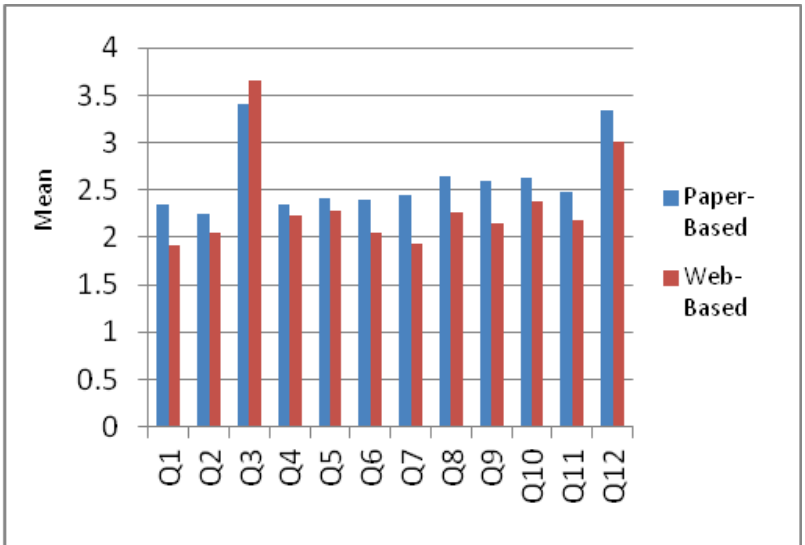

Figure 2. Mean value for the paper-based and web-based questionnaires

For $\mathrm{H} 2$, the mean scores for degree year one, were higher except for questions 3 and 12. The results have shown that for these two questions the mean scores were higher for the preparatory year. There was a significant difference $(\mathrm{p}<0.05)$ for questions 5, 6, 11 and 12 (see Figure 3). 


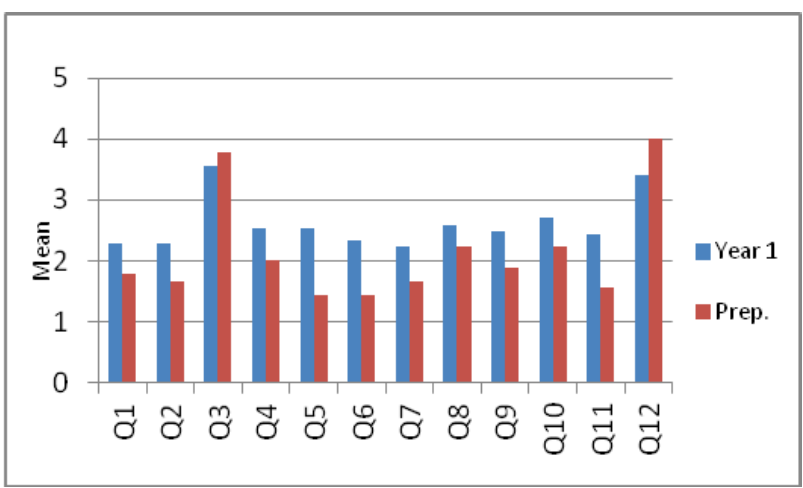

Figure 3. Mean value for Year 1 and Prep questionnaires

For H3, there was a significant difference between students from the Department of Informatics and Computing and the Department of Engineering with regard to answering questions 4,11 , and $12(\mathrm{p}<0.05)$. The mean scores of these questions for engineering students' were higher.

There was a significant difference between students responses from the Faculty of Informatics and Computing and Political Science and Business with questions 5, 6, and $9(p<0.05)$. The mean scores for Political Science and Business students' were higher.

There was a significant difference between students responses from the Faculty of Informatics and Computing when compared with those from Pharmacy with questions 2, 5, 6, 7, 11 and $12(\mathrm{p}<0.05)$. The mean scores of Pharmacy students' were higher.

There was a signeificant difference between students responses from the Faculty of Informatics and Computing and the Faculty of Dentistry in answering questions 5, and $6(\mathrm{p}<0.05)$. The mean scores for Dentistry students' were higher.

There was a significant difference between the responses of students from the Faculty of Engineering and the Department of Political Science and Business in answering question $3(\mathrm{p}<0.05)$. The mean scores of question 3 were higher for engineering students.

There was a significant difference between students from the Faculty of Engineering and the Faculty of Pharmacy in answering questions 4,5 , and $6(\mathrm{P}<0.05)$. The mean scores of these questions for Pharmacy students' were higher.

There was a significant difference between the responses of students from the Faculty of Engineering and the Faculty of Dentistry in answering questions 1, 2, and 12 $(\mathrm{P}<0.05)$. The mean scores of the questions for dentistry students' were higher except for question 2 which was higher for engineering students.

There was a significant difference between students responses from the Department of Political Science, Business and the Faculty of Pharmacy in answering question 2 $(\mathrm{P}<0.05)$. The mean scores for Pharmacy students' were higher.

There was a significant difference between students responses from the Departments of Political Science and Business and the Faculty of Dentistry in answering question $2(\mathrm{P}<0.05)$. The mean scores for Political Science and Business were higher (see Figure 4).

For $\mathrm{H} 1$ and $\mathrm{H} 3$, Table II and figure 5, illustrates students distributions among the faculties at the (BUE)[19],

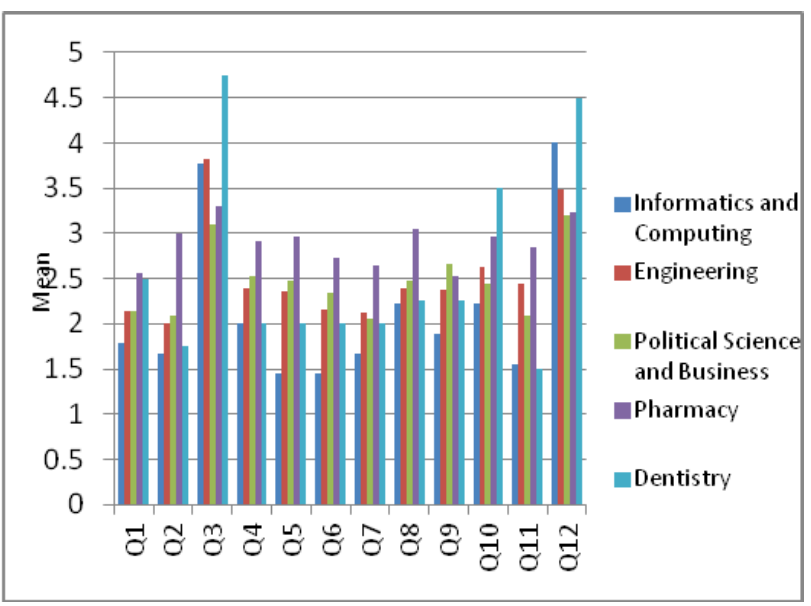

Figure 4. Mean value of the Faculties

TABLE II.

NUMBER OF STUDENTS PARTICIPATION

\begin{tabular}{|l|c|c|c|}
\hline & $\begin{array}{c}\text { Paper- } \\
\text { Based }\end{array}$ & $\begin{array}{c}\text { Web- } \\
\text { based }\end{array}$ & Total \\
\hline Engineering & 18 & 39 & 57 \\
\hline Political Science and business & 11 & 7 & 18 \\
\hline Pharmacy & 18 & 11 & 29 \\
\hline Dentistry & 18 & 2 & 20 \\
\hline Total & 65 & 59 & 124 \\
\hline
\end{tabular}

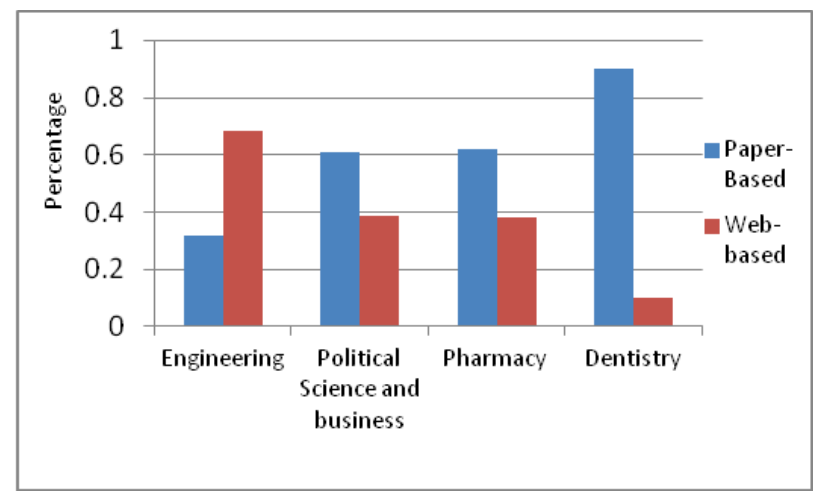

Figure 5. Percentage of students participations

who are studying English modules and participated in the study. A significant number of students in the Faculty of Engineering chose the web-based exercises over the studenst in the other faculties. There was a significant difference between the paper-based and web-based exercises for students in the Faculties of Engineering and Dentistry $(\mathrm{P}<0.05)$.

From the entire above hypothesis H1, H2, and H3 had been accepted.

\section{B. Study 2}

This study investigated H4 and H5. The hypothesis H4 was testing whether there was a relationship between the web-based exercise scores and the student's preference to e-learning activities. The analysis of the study conducted at the (BUE)[19] compares the Digital Design and Computer Graphic modules. The study showed that students who used web-based activities received a higher score. Moreover, they had a higher rate in answering the 12 questions. 
At the (BUE)[19], the first group was students of Computer Graphics Module. Twelve students participated in the paper based exercise, 7 students in the online based exercise, and totally 17 students completed the questionare survey. The second group was students of Digital Design Module. 52 students participated in the paper based exercise. 30 students paticipated in the online based exercise and totally 23 students in the completition of the questionare survey.

Students performed better in the online exercises in the Digital Design Model, as shown in Figures 6 and 7. The results presented in Figure 6 have been normalized, so the highest value is one. The mean of the online-exam questionnaire responses for the Digital Design was higher than the Computer Graphics modules, as shown in Figure 7. The maximum scale value for the questionnaire was 5 , as mentioned in section II.

There was a significant difference between Digital Design and the Computer Graphics modules for almost all the 12 questions of the questionnaire survey $(\mathrm{P}<0.05)$ (see Figure 8).

Two different groups of students in the Data Structure Module at Helwan university [6] were also involved in this study. The first group consisted of 17 students who participated in the completition of the paper-based exercises and the questionnaire respectively. The second group consisted of 25 students who participated in the completition of the on-line exercises and the questionnaire respectively.

The mean scores of the paper-based exercises were higher than the online exercises. However, the mean scores of the questionnaire were higher for the online exercise when compared with the paper-based exercises (see Table III). There were no significant differences between the two sets of mean scores in responses to the survey questions.

The mean scores of the questionnaire at Helwan University [6] were higher than he mean scores at the British University (see Table IV).

There was a significant difference for all questions between the modules conducted at the (BUE) [14][16] and Helwan University[6] $(\mathrm{p}<0.05)$ except for question 12 (see Table V).

For H5, table VI shows the results of four teachers that were assigned to teach English Module to different groups of students at the (BUE)[19]. The table reflects the number of students that chose either paper-based or web-based exercises. Figure 9 shows the percentage of the students that chose either paper-based or web-based exercises for each teacher.

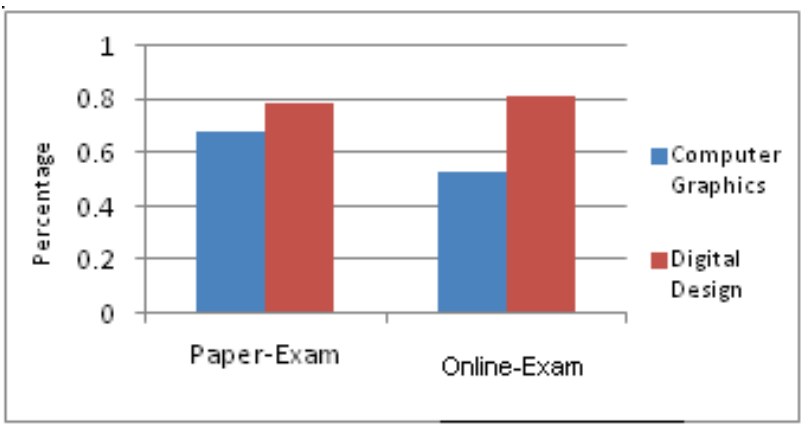

Figure 6. Normalized results of the exercises

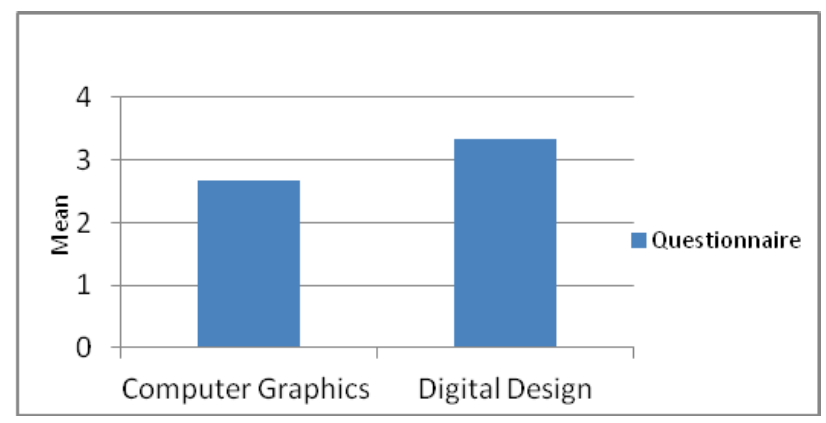

Figure 7. Mean value of the 12 questions of the online-exam questionnaire

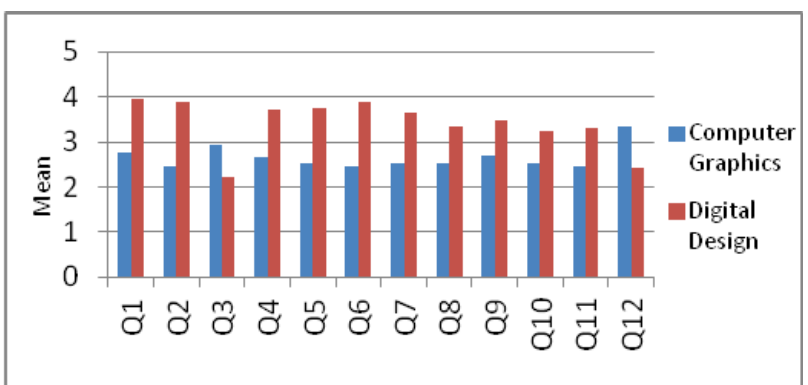

Figure 8. Figure 8. Mean value of the questiones at the questionaire for the computer graphics (CG) and the digital design (DD) modules.

TABLE I.

MEAN OF THE EXAMS AND QUESTIONNAIRE

\begin{tabular}{|l|l|l|}
\hline & \multicolumn{1}{|c|}{ Paper } & \multicolumn{1}{c|}{ Online } \\
\hline Exam & 54.27381 & 46.71429 \\
\hline Questionnaire & 3.612745 & 3.733333 \\
\hline
\end{tabular}

TABLE II.

MEAN VALUE OF THE QUESTIONNAIRE FOR (BUE)[19] AND HELWAN [6] UNIVERSITIES

\begin{tabular}{|l|l|}
\hline & \multicolumn{1}{|c|}{ Questionnaire Mean } \\
\hline Computer Graphics, BUE, online-exam & 2.661765 \\
\hline Digital Design, BUE, online-exam & 3.344203 \\
\hline Data Structure, Helwan, online-exam & 3.733333 \\
\hline
\end{tabular}

TABLE III.

MEAN VALUE OF QUESTION 12 AT THE QUESTIONNAIRE FOR (BUE) [14][16] AND HELWAN [6] UNIVERSITIES

\begin{tabular}{|l|l|}
\hline & \multicolumn{1}{|c|}{ Mean } \\
\hline Q12-Helwan-(Online) & 2.764706 \\
\hline Q12-Helwan-(Paper-based) & 2.941176 \\
\hline Q12-BUE-CG & 3.352941 \\
\hline Q12-BUE-DD & 2.411765 \\
\hline
\end{tabular}

TABLE IV

4 TEACHERS VS. NUMBER OF STUDENTS WHO DECIDED TO CHOOSE PAPER-BASED OR WEB-BASED

\begin{tabular}{|c|c|c|c|}
\hline Teacher & Paper-Based & Web-based & Total \\
\hline 1 & 7 & 17 & 24 \\
\hline 2 & 17 & 14 & 31 \\
\hline 3 & 35 & 13 & 48 \\
\hline 4 & 6 & 15 & 21 \\
\hline Total & 65 & 59 & 124 \\
\hline
\end{tabular}




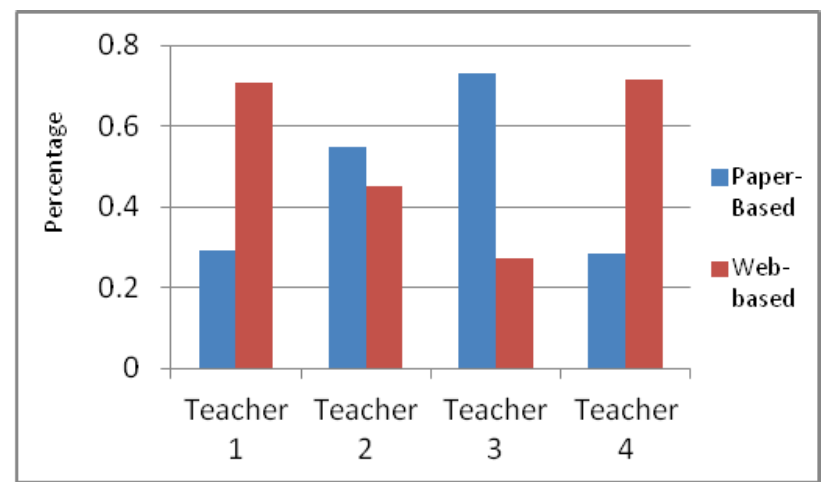

Figure 9. 4 teachers vs. percentage of students who decided to choose paper-based or web-based

From the above studies, it can be concluded that there was no relationship between getting a high score in the web-based exercises and answering the 12 questions at a high rate. In that respect, hypothesis H5 can be accepted and hypothesis $\mathrm{H} 4$ rejected. One possible reason for this finding is the different factors that can influence the result, such as, the module nature, module leader i.e. lecturer, or the difficulty of the exercise questions. Moreover, this requires further investigation.

\section{Discussion AND Findings}

Many studies have shown that effective use of elearning could help increase student motivation engagement, and attendance. It should also increase student class participation, and improved behavior and performance on core subjects.

One of the crucial factors for students' success in elearning process is self-motivation. The Integration of information and communication technologies with the learning process depends on the participants' personal motivation. In order to enable students to maximize the ICT potential in their learning process, students need to be supported with their digital enhanced learning.

However, many studies have shown that non IT students need to increase the level of their technological and communication skills to be able to benefit significantly from the opportunities offered by e-learning. The lack of confidence and experience in using technology might be extra obstacle for other students. In e-learning process, students work independently and some students might find it difficult to understand their contents, due to the lack face-to-face contact with instructors and other fellow students. All these factors indicate that these students will not be able to participate effectively and succeed in the elearning process. Consequently, in order to appropriately progress and successfully use all e-learning tools to effectively access online information, some students need the necessary hardware and some specific skills. Certainly, ELearning would increase the motivation and engagement of students for learning and help them to become self directed independent learners.

On the one hand, teachers need to develop and restructure their courses in a way that suits online requirements. It is very clear that such activities require more time and increase the workload. On the other hand, instructors and faculty members must honor, possess and master all technical achievements and new advancements offered by ELearning. In order to maintain the quality of the courses offered via E-learning, faculty members and instructors must review and modify the teaching approaches used in traditional courses. Moreover, new educational approaches must be adopted. Unfortunately, some teachers still remain unconvinced about the integration of technology into their learning process and are also reluctant to change their work patterns and teaching style. To help instructors during the transition period will require management support together with resources and sufficient time allocation. However, it is very difficult to quantify the precise nature of the change.

It is evident that E-Learning success in higher education depends on effectiveness of delivery and adequate training of instructors in the adoption of E-Learning initiatives. Inadequately trained staff can become an obstacle in a finely balanced learning process and can lead to problems in application use and in the perception of students.

\section{CONCLUSION AND FURTHER WORKS}

This study has reported some important findings about online education, confuted others and presented a range of predictions about the future of online technology for educational purposes.

Instructors need to understand their student motivations when teaching online classes. However, it can be difficult to assess student motivations for online learning due to the lack of personal contact between the students and instructor. One way to avoid this is to have the students complete an online assessment form on motivation. From the information obtained, a teacher can identify a number of strategies to engage the students and keep them motivated. Most importantly, it should be noted that more technology does not necessarily lead to better learning outcomes.

Instructors who taught the participants of the study should be interviewed to get feedback in order to evaluate e-learning from a teacher's perspective. The interview questions should focus on evaluating e-learning and the implications for enhancing the quality of learning and teaching through e-learning.

The questions should include:

1. Demographics of online instructors and theirexpectations (teaching positions, e.g. professors, instructors and TAs)

2. Emerging technology and effect of using course management systems (CMSs)

There is some evidence which links the instructors and students with regard to the preferences of web-based or paper-based. This requires further investigations.

It is expected that improvements in Internet technology (i.e. greater bandwidth and wireless Internet connection) are likely to increase the use of multimedia in education. Moreover, it is expected that technology would most influence the delivery of online learning. It is planned to use other Multimedia tools of the e-learning in future studies.

The question is: are online instructors ready to meet the $21^{\text {st }}$ century challenges brought by this generation's demand for the use of technology in education and specifically online learning?

\section{REFERENCES}

[1] A. Edmundson, Globalized e-learning cultural challenges. (USA: Idea Group Inc), 2007.

[2] B. O'Connell, "A Poor Grade for ELearning. (Classroom Students Did Better)”, Workforce, 81(7), 15. 
[3] B.R. Worthen , J.R. Sanders, Educational evaluation: Alternative approaches and practical guidelines. White Plains, NY: Longman, 1987.

[4] D. Holley, "Which room is the virtual seminar in please?", Education and Training, 44(3), 112-121. http://dx.doi.org/10.1108/ 00400910210424283

[5] D. Picar, "E-Learning and Motivation", White Paper, ITEC at SFSU, 2004. Retrieved from http://itec.sfsu.edu/wp/860wp/f04 860 picar elearning motivation.pdf

[6] Helwan University, http://www.helwan.edu.eg/english/

[7] H Li, J. Masters, "ELearning and knowledge management in the early years: Where are we and where should we go", Knowledge Management and eLearning: An International Journal, 2009, 1(4), 245-250.

[8] K. Cheng, A Research Study on Students' Level of Acceptance in Applying E-Learning for Business Courses - A Case Study on a Technical College in Taiwan. Journal of American Academy of Business. 2006, Volume 8. Number 2. pp: 265-270.

[9] K.H. Fee, Delivering E-Learning: A Complete Strategy for Design Application and Assessment, 2005, London and Philadelphea: Kogan Page.

[10] L. Maltz, P. Deblois, The EDUCAUSE Current Issues Committee, “Top Ten IT Issues”., EDUCAUSE Review, 40(1), 15-28.

[11] MCIT, (2008) Information and Communications Technology Indicators Bulletin.

[12] M. Elkhouly, Cases on challenges facing e-learning and national development: Institutional Studies and Practices, elearning in EGYPT, Volume I, Editor: Ugur Demiray, Anadolu University, Eskisehir-Turkey, 2010

[13] M. Nehme, "E-Learning and Students' Motivation", (2010) 20 Legal Education Review, 223-239, SSRN-id2347142, 2010. Retrieved from SSRN: http://ssrn.com/abstract=2347142

[14] S. Abou El-Seoud, N. Seddiek, I. A.T.F. Taj-Eddin, P. Ghenghesh, A. Nosseir, M. M. El-Khouly. "E-Learning and Motivation Effects On Egyptian Higher Education", $16^{\text {th }}$ International Conference on Interactive Collaborative Learning (ICL2013) and $42^{\text {nd }}$ International Conference on Engineering Pedagogy, September $25^{\text {th }}-27^{\text {th }}$ , 2013, ISBN:978-1-4799-0152-4/13, C2013 IEEE , 714-720, Kazan, Russia.

[15] R.J. Wlodkowski, "Adults in Modern Society are on a Lifelong Educational Journey”, 2005. Retrieved from http://userpages.umbc.edu/ koconne1/605TheAdultLearner/elearn ing.htm
[16] S. El-Seoud, N. Seddiek, I. Taj-Eddin, P. Ghenghesh, M. ElKhouly, "The Effect of E-learning on Learner's Motivation: A Case Study on Evaluating E-Learning and its Effect On Egyptian Higher Education", The International Conference on E-Learning in the Workplace 2013 (ICELW 2013), June $12^{\text {th }}-14^{\text {th }}, 2013$, ISBN:978-0-9827670-3-0, New York, NY, USA.

[17] S.Z. Keith, "Self-assessment materials for use in portfolios", Primus, June 1996, 6(2), 178-192. http://dx.doi.org/10.1080/ 10511979608965822

[18] T. FitzPatrick, "Key Success Factors of eLearning in Education: A Professional Development Model to Evaluate and Support eLearning", US-China Education Review, 2012, A 9 , 2012, 789-795.

[19] The British University in Egypt, http://www.bue.edu.eg

[20] The Future of the Internet Technology in Egypt, A Statistical Profile, March 2009, Ministry of Communication and Information Technology, Egypt. Retreive from: http://www.new.egyptict indicators.gov.eg/en/Publications/PublicationsDoc/The\%20Future $\% 20$ of $\% 20$ the $\% 20$ Internet $\% 20$ Economy $\% 20 \% 20$ Version $\% 20$ II.p df

\section{AUTHORS}

M. Samir Abou El-Seoud is with the Faculty of Informatics and Computer Science, British University in Egypt-BUE, Cairo, Egypt.

Islam A.T.F. Taj-Eddin is with the Faculty of Informatics and Computer Science, British University in Egypt-BUE, Cairo, Egypt.

Naglaa Seddiek is with the English Department, British University in Egypt-BUE, Cairo, Egypt.

Mahmoud M. El-Khouly is with the Faculty of Computers \& Information, Helwan University, Cairo, Egypt.

Ann Nosseir is with the Faculty of Informatics and Computer Science, British University in Egypt-BUE, Cairo, Egypt.

This is a revised, extended and enhanced version of a presentation given at ICL 2013 conference in Kazan/Russia. Submitted 07 December 2013. Piublished as resubmitted by the authors 14 June 2014. 